Review

\title{
Insect ATP-Binding Cassette (ABC) Transporters: Roles in Xenobiotic Detoxification and $\mathrm{Bt}$ Insecticidal Activity
}

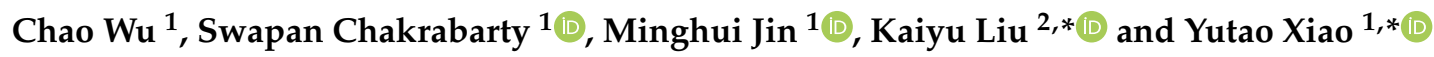 \\ 1 Agricultural Genomics Institute at Shenzhen, Chinese Academy of Agricultural Sciences, \\ Shenzhen 518120, China; wuchao@caas.cn (C.W.); swapan.ag.sau@gmail.com (S.C.); \\ jinminghui722@163.com (M.J.) \\ 2 Institute of Entomology, School of Life Sciences, Central China Normal University, Wuhan 430079, China \\ * Correspondence: liukaiyu@mail.ccnu.edu.cn (K.L.); xiaoyutao@caas.cn (Y.X.); \\ Tel.: +86-27-67867221 (K.L.); +86-755-28473240 (Y.X.)
}

Received: 22 May 2019; Accepted: 6 June 2019; Published: 10 June 2019

\begin{abstract}
ATP-binding cassette $(\mathrm{ABC})$ transporters, a large class of transmembrane proteins, are widely found in organisms and play an important role in the transport of xenobiotics. Insect $A B C$ transporters are involved in insecticide detoxification and Bacillus thuringiensis $(\mathrm{Bt})$ toxin perforation. The complete $\mathrm{ABC}$ transporter is composed of two hydrophobic transmembrane domains (TMDs) and two nucleotide binding domains (NBDs). Conformational changes that are needed for their action are mediated by ATP hydrolysis. According to the similarity among their sequences and organization of conserved ATP-binding cassette domains, insect $A B C$ transporters have been divided into eight subfamilies (ABCA-ABCH). This review describes the functions and mechanisms of $A B C$ transporters in insecticide detoxification, plant toxic secondary metabolites transport and insecticidal activity of Bt toxin. With improved understanding of the role and mechanisms of $\mathrm{ABC}$ transporter in resistance to insecticides and Bt toxins, we can identify valuable target sites for developing new strategies to control pests and manage resistance and achieve green pest control.
\end{abstract}

Keywords: insect; $\mathrm{ABC}$ transporters; xenobiotic detoxification; Bt insecticidal activity

\section{Introduction}

ATP-binding cassette $(\mathrm{ABC})$ proteins comprise an extensive and variable transporter superfamily within P-loop motif and are found in all living organisms [1-3]. Studies on ABC transporters began in the early 1970s with the biochemical characterization of substrate-binding protein-dependent transport in Escherichia coli that was directly energized by hydrolysis of ATP [4,5]. In 1982, cytoplasmic membrane-associated transporter genes in the histidine transport system of Salmonella typhimurium (coded by the hisP gene) and maltose-maltodextrin transport system of E. coli (coded by the malK gene) were cloned [6,7]. Concurrently, in mammalian cells, the gene encoding permeability, glycoprotein (P-gp, a large glycosylated membrane protein related to multi-drug resistance) was identified and cloned in 1985 [8,9]. Eventually, substrate-binding transport proteins with ATP-binding subunits were found to constitute a large superfamily of transport proteins and termed ABC transporters in 1990 [10]. On the basis of differences in the ATP-binding sites among insect ABC transporters, the superfamily can be divided into eight subfamilies (ABCA to $\mathrm{ABCH}$ ) [11].

The primary function of most ABC proteins is ATP-dependent active transport of a broad spectrum of substrates including amino acids, sugars, heavy metal ions and conjugates, peptides, lipids, polysaccharides, xenobiotics and chemotherapeutic drugs across cellular membranes [1,12-14], but they are also involved in many other biochemical and physiological processes. In humans, they have 
also been shown to function as ion channels and receptors $[1,12,15]$. Because of their ability to transport chemotherapeutic drugs and other hydrophobic substrates such as lipids and hormones, many human $A B C$ superfamily members have been identified as the agent responsible for multidrug-resistance in cancer cells. In fact, the P-glycoprotein ABCB1 (also known as MDR1, multidrug-resistance protein 1), that is overexpressed in multidrug resistant tumor cell lines, was the first $A B C$ protein identified as such $[9,16]$.

Although the $\mathrm{ABC}$ transporters have been recognized to be associated with multidrug resistance in humans, bacteria and nematodes, their functional role in arthropods has not been fully studied [17]. Although studies on insect $A B C$ transporters were triggered because they are associated with the evolving field resistance to different Bt toxins and insecticides, the scope of studies on insect $A B C$ transporters has greatly expanded with the advancement of sequencing technology and the annotation of more insect genomes. The availability of insect genome databases provide genomic insights for analyzing the comparative positions and phylogenetic relationships of $\mathrm{ABC}$ transporter genes among genetically distant species. The white gene in Drosophila melanogaster was the first identified insect $\mathrm{ABC}$ transporter gene and is involved in the transport of eye pigment precursors [18]. The role of a gene orthologous to white has also been confirmed in Bombyx mori and Tribolium castaneum $[19,20]$. The upregulation of some $A B C$ transporter genes is associated with resistance to highly effective insecticides such as pyrethroids in some insects [21-23]. It is also reported that alterations in the $A B C C$ genes are associated with the resistance to Cry toxins from Bacillus thuringiensis (Bt) by reducing the binding affinity of Cry toxins to the brush border membrane vesicles in different lepidopteran species [24-26]. On the basis of above mentioned evidences, it is noteworthy that ABC transporters have important role in xenobiotic detoxification and Bt-resistance.

Excellent reviews on the role of insect $A B C$ transporters in the transport and resistance to $\mathrm{Bt}$ toxin and insecticide have been published previously $[14,27,28]$, so the present review provides an update of our understanding of the evolution, function and role of the $A B C$ transporter superfamily of insects in xenobiotic transport and detoxification.

\section{Structure and Mechanism of ABC Transporters}

Structural models of $A B C$ transporters are based on the crystal structure of different bacterial proteins that act as importers such as vitamin B12 transporter BtuCDF from E. coli and exporters such as the multidrug exporter Sav1866 from Staphylococcus aureus or related flippases such as MsbA lipid flippase from E. coli [29-31]. On the basis of their architecture and biochemical activity, the ABC importers have been divided into type I and type II [12,32,33]. The energy coupling factor (ECF) transporters, which differ structurally and functionally from other $\mathrm{ABC}$ importers, are sometimes considered as type III ABC importers [34-37]. However, ABC importers have only been confirmed in prokaryotes, not in eukaryotes [11,15]; therefore, in this review, we focus only on ABC exporters.

The structure of $\mathrm{ABC}$ transporters is highly conserved among most eukaryotic organisms, including insects. A functional $\mathrm{ABC}$ transporter is characterized by the presence of a P-type traffic ATPase, which comprises two cytosolic nucleotide-binding domains (NBDs) and two transmembrane domains (TMDs) [1,12,38] (Figure 1A). The four domains of a functional transporter (2TMDs-2NBDs) are combined in a single polypeptide, forming a full transporter (FT), whereas a half transporter (HT) contains one TMD and one NBD, which are sometimes encoded as separate polypeptides and then fused into multidomain proteins. For ATP binding and hydrolysis, the HT must become a functional transporter by forming homo- or heterodimeric complexes. The NBD contains several highly conserved nucleotide-binding sequences such as the Walker A and B motifs, common in nucleotide-binding proteins (the Walker B motif also provides the catalytic base); D-loop, which contains an aspartate residue and is responsible for forming a salt bridge; $\mathrm{Q}-\mathrm{loop}$, which contains a glutamate residue and acts as the attacking nucleophile in ATP hydrolysis; $\mathrm{H}$ motif, which has an invariant histidine active site that may be involved in maintaining the stability of the pre-hydrolytic state; and an $\alpha$-helical region that has the ABC signature sequence (LSGGQ motif) $[12,13,39]$. The ABC exporter fold, a prominent 
quaternary structure in TMDs in all $\mathrm{ABC}$ exporters, is characterized by 12 transmembrane helices and acts as a switch between different conformational changes and initiates substrate translocation [12].

$\mathrm{ABC}$ transporters have a common mechanism for exporting substrates across the membrane by hydrolyzing ATP as a pump, but other models have been proposed for the ABC transporter mechanism based on structural and biochemical evidence, including the ATP-switch [39], alternating site [40], constant contact [41,42], and thermodynamic models [43]. Among these models, the ATP-switch model provides a reasonable framework for the transport mechanism $[39,44,45]$ in which repeated communication between NBDs and TMDs occurs in both directions and involves only non-covalent conformational changes. The transport process is initiated by the binding of the substrate to the TMDs, and subsequent structural changes are transmitted to the NBDs, which include ATP-binding and closed dimer formation of the NBDs. Then the closed NBD dimer induces a substantial conformational change in the TMDs. This conformational change initiates translocation of the substrate through a rotation of the TMDs and opening toward the extracellular milieu. Finally, the ATP is hydrolyzed, releasing ADP and $\mathrm{Pi}$ and destabilizing the closed dimer conformation to restore its open dimer configuration for another new cycle [39,44,45] (Figure 1B).

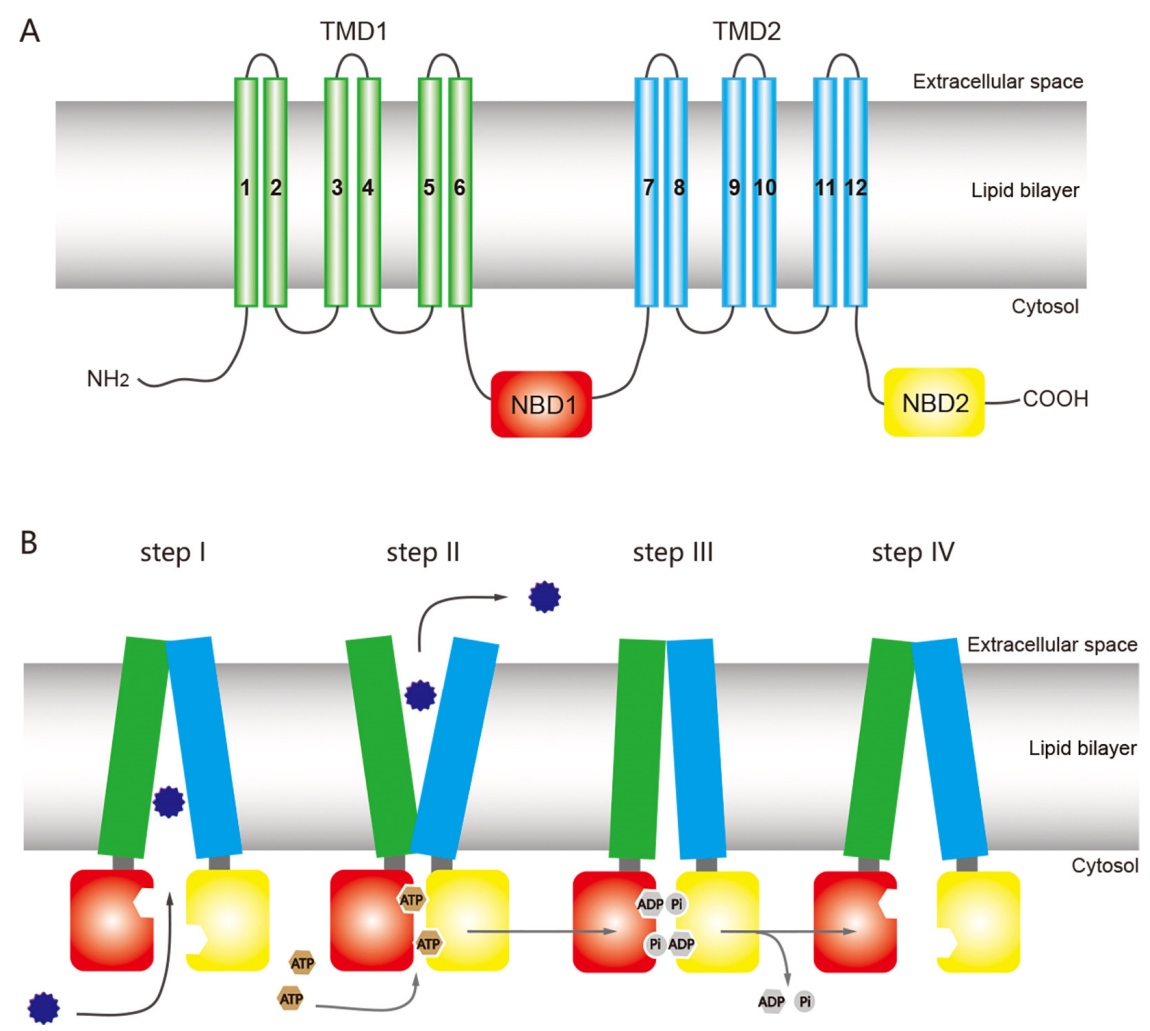

Figure 1. General structure of an ATP-binding cassette $(A B C)$ full transporter (ABC exporter) and the ATP-switch model for the transport mechanism of ABC transporters. (A) Typical ABC full transporter with two transmembrane domains (TMDs), TMD1 (green) and TMD2 (sky blue), and two nucleotide-binding domains (NBDs), NBD1 (red) and NBD2 (yellow). Each transmembrane domain (TMD) contains six transmembrane helices. The "long" multidrug-resistance associated proteins (MRPs) of the ABCC subfamily contains an additional TMD (TMD0) at the N terminus [46]. (B) The ATP-switch model [14] includes (I) binding of the substrates (12-point blue circle) to the TMDs; (II) subsequent structural changes to the NBDs (red and yellow), hydrolysis of ATP (brown circles), followed by closed dimer formation of the NBDs and major conformational change in the TMDs, which initiates substrate translocation; (III) the ATP is hydrolyzed (gray circles), releasing ADP and Pi, and (IV) finally destabilization of the closed dimer restores its initial open dimer configuration for another new cycle. This figure is drawn by following the previous report of ABC transporter by Dermauw \& Van Leeuwen [14]. 


\section{ABC Transporter Subfamilies in Insects}

In recent years, with the large-scale development of genome sequencing technology, the sequencing results have shown that $A B C$ transporter genes are highly conserved in many insects (Figure 2). Aside from some important discoveries on the function of some $A B C$ transporters in insects, however, knowledge on the role and function of these proteins is still limited. $A B C$ transporters of numerous important agricultural pests and model insects, such as D. melanogaster, B. mori, Helicoverpa armigera and Plutella xylostella, have been reported (Table 1).

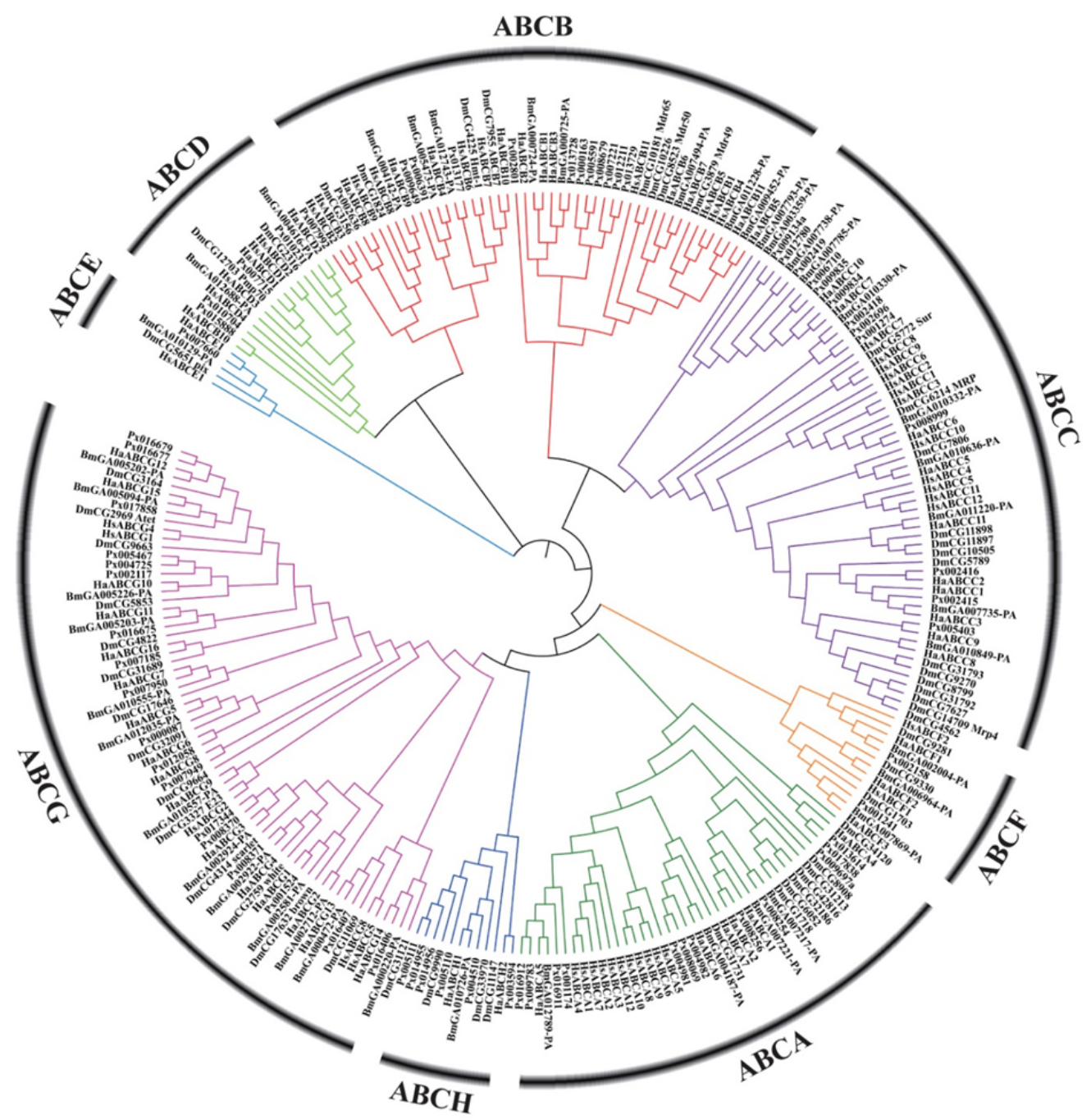

Figure 2. Phylogenetic tree based on amino acid sequences of 262 ABC transporters (Supplementary Material 1) from several insects and humans. The sequences were aligned using MUSCLE. The evolutionary history was inferred using the neighbor-joining method and MEGA-X with 1000 bootstrap replicates. All positions with less than 95\% site coverage were eliminated. Species codes: Ha, Helicoverpa armigera; Bm, Bombyx mori; Px, Plutella xylostella; Hs, Homo sapiens; Dm, Drosophila melanogaster. 
Table 1. Distribution of genes among ABC transporter subfamilies for different arthropods and Homo sapiens.

\begin{tabular}{|c|c|c|c|c|c|c|c|c|c|c|}
\hline Organisms & A & B & $\mathrm{C}$ & $\mathbf{D}$ & $\mathbf{E}$ & $\mathbf{F}$ & G & $\mathbf{H}$ & Total & References \\
\hline Homo sapiens & 12 & 11 & 12 & 4 & 1 & 3 & 5 & 0 & 48 & [1] \\
\hline Drosophila melanogaster & 10 & 8 & 14 & 2 & 1 & 3 & 15 & 3 & 56 & [1] \\
\hline Anopheles gambiae & 9 & 5 & 13 & 2 & 1 & 3 & 16 & 3 & 52 & [47] \\
\hline Daphnia pulex & 4 & 7 & 7 & 3 & 1 & 4 & 24 & 15 & 65 & [48] \\
\hline Pediculus humanus humanus & 2 & 6 & 5 & 2 & 1 & 3 & 13 & 6 & $40^{\mathrm{a}}$ & [49] \\
\hline Apis melifera & 3 & 5 & 9 & 2 & 1 & 3 & 15 & 3 & 41 & [50] \\
\hline Bombyx mori & 7 & 9 & 11 & 2 & 1 & 3 & 16 & 2 & $51^{\mathrm{b}}$ & [50-52] \\
\hline Tribolium castaneum & 10 & 6 & 35 & 2 & 1 & 3 & 13 & 3 & 73 & [20] \\
\hline Tetranychus urticae & 9 & 4 & 39 & 2 & 1 & 3 & 23 & 22 & 103 & [53] \\
\hline Chrysomela populi & 5 & 8 & 29 & 2 & 1 & 3 & 14 & 3 & 65 & [54] \\
\hline Lygus hesperus & 11 & 6 & 12 & 2 & 1 & 3 & 19 & 11 & 65 & [55] \\
\hline Lepeophtheirus salmonis & 3 & 4 & 11 & 3 & 1 & 4 & 2 & 5 & 33 & [56] \\
\hline Laodelphax striatellux & 2 & 6 & 5 & 2 & 1 & 2 & 14 & 8 & 40 & [57] \\
\hline Bemisia tabaci & 8 & 3 & 6 & 2 & 1 & 3 & 23 & 9 & 55 & [58] \\
\hline Plutella xylostella & 15 & 14 & 21 & 3 & 1 & 3 & 19 & 6 & 82 & {$[59,60]$} \\
\hline Manduca sexta & 7 & 9 & 11 & 2 & 1 & 3 & 13 & 3 & 52 & {$[60]$} \\
\hline Danaus plexippus & 8 & 16 & 12 & 3 & 1 & 3 & 16 & 3 & 62 & [60] \\
\hline Heliconius melpomene & 10 & 11 & 15 & 2 & 1 & 3 & 17 & 3 & 62 & [60] \\
\hline Helicoverpa armigera & 7 & 11 & 11 & 2 & 1 & 3 & 17 & 2 & 54 & {$[52,61,62]$} \\
\hline Helicoverpa zea & 7 & 11 & 11 & 2 & 1 & 3 & 17 & 2 & 54 & [52] \\
\hline Acyrthosiphon pisum & 11 & 9 & 16 & 2 & 1 & 4 & 19 & 9 & 71 & {$[63,64]$} \\
\hline
\end{tabular}

${ }^{a}$ Includes two uncharacterized ABC transporters. ${ }^{b}$ The number of B. mori ABC transporter genes in the different subfamilies is mainly based on the latest report [52], but were reported previously [50].

\subsection{The ABCA Subfamily}

According to the distinctive conserved traits, ABCA subfamily proteins can be divided into full transporters (FTs) and half transporters (HTs); the number of insect $A B C A$ genes differs among different species (3-15). ABCA genes that encode only FTs are present in T. castaneum, Anopheles gambiae, D. melanogaster, Apis mellifera, Daphnia pulex, Tetranychus urticae and Bemisia tabaci $[11,58]$. Two FTs and five HTs have been found in one analysis of the B. mori genome [51], whereas another showed two FTs, one HT and three incomplete ABC sequences (These sequences were derived from a sequenced and assembled genome, but the genomic scaffold is incomplete.) [50]. In mammals, ABCA transporters function in controlling cellular lipid transport [65], but little is known about their specific function in insects. Silencing of TcABCA-9A or TcABCA-9B in T. castaneum by injection of dsRNA leads to developmental defects in the wings and elytra and to about $30 \%$ mortality at the adult eclosion stage [20]. This silencing study provides a direction for the functional analysis of insect ABCA subfamily genes. The flight capability of insects is related to lipid metabolism, the biosynthesis of various lipid classes, and the total lipids and triglycerides provide energy for flight [66,67]. As in mammals, ABCA proteins may function in lipid transport in insects, so the developmental defects in wings and elytra are likely due to loss of lipid transport. In addition, ABCA2 is also associated with insect resistance to Bt toxin [68].

\subsection{The $A B C B$ Subfamily}

ABCB subfamily transporters also contain FTs and HTs. In the genome of T. castaneum, An. gambiae, D. melanogaster, B. mori and A. mellifera, the number of FTs are 2, 2, 4, 5 and 1 , and the number of HTs are 4, 3, 4, 4 and 4, respectively. A. mellifera also contains two incomplete ABCB sequences. Similarly, two genes encoding FTs, and five and two genes encoding HTs were found in the D. pulex and T. urticae genomes, respectively. The function of the ortholog of the human half transporter HsABCB7 in D. melanogaster was studied by RNA interference and found to play a key role in cellular iron homeostasis [69]. CG4225, homologous to human $A B C B 6$ in D. melanogaster, is also known as DmHMT-1, which is responsible for resistance against cadmium [70]. Another ABCB transporter gene, CG7955 in D. melanogaster, is correlated with chill coma stress resistance [71]. The perineurium in lepidopterans serves as a diffusion barrier for polar cardenolides and provides an active barrier for 
non-polar cardenolides, and the P-glycoprotein-like transporter mediates the efflux of cardenolides in the nerve cord, thereby preventing interaction of these toxins with the susceptible target site in $\mathrm{Na}^{+} / \mathrm{K}^{+}$-ATPase [72].

\subsection{The ABCC Subfamily}

The functions of ABCC subfamily in mammals mainly include ion transport, signal transduction, and toxin secretion [1]. The ABCC transporters in insect may have similar functions. Usually, insect genomes contain 9-16 ABCC genes, with the most found to date in T. urticae, followed by T. castaneum and Chrysomela populi. There are 35 genes encoding ABCC transporters in T. castaneum, and expansion of TcABCC gene mainly occurs on chromosome 5 and affects genes of the "short" MRP group [20]. The ABCC subfamily of $B$. mori can be divided into two groups, one of which has very high similarity with the $A B C B$ subfamily [50]. The B. mori ABCC subfamily consists of five FTs, seven HTs and three incomplete $\mathrm{ABC}$ sequences. The $\mathrm{ABCC}$ transporters of most insects with known genomes are also composed of FTs and HTs, except for D. melanogaster; its 14 ABCC transporters are FTs. Some ABCC transporters also contain an additional N-terminal TMD (TMD0) [46] and have been found in the genome of D. pulex, An. gambiae, D. melanogaster and T. castaneum [20,47,48].

\subsection{The $A B C D, A B C E$ and $A B C F$ Subfamilies}

The ABCD subfamily is composed of highly conserved HTs, located on the peroxisome membrane, that form heterodimers and mediate the transport of acyl coenzyme A esters in organisms [73,74]. Most insects with sequenced genomes have two $A B C D$ genes, but a few insects, such as Danaus plexippus and P. xylostella, contain three $[59,60]$. Because of the high sequence similarity between insects and other eukaryotes, including humans, they may be involved in similar peroxisomal pathways [11].

Compared with other $\mathrm{ABC}$ transporters, both $\mathrm{ABCE}$ and $\mathrm{ABCF}$ proteins have no TMDs, and each member contains a pair of adjacent NBDs [75]. Due to their lack of transmembrane structure, proteins in these two subfamilies do not have a translocation function [76]. Almost all insects, and even most eukaryotes, contain only one $A B C E$ gene, which is highly conserved [50]. The ABCF subfamily is also highly conserved. Similar to human ABCF proteins, most of the known insect genomes have three $\mathrm{ABCF}$ proteins. They are divided into three distinct groups by phylogenetic analysis, and the genes in each group is highly similar [50]. $\mathrm{ABCE}$ and $\mathrm{ABCF}$ proteins are universally found in eukaryotes and are important in ribosome biogenesis, translation control and mRNA output [76-78]. ABCE is annotated as RNase L (Rli1) inhibitor in eukaryotes and may have a general function in innate immunity [79]. Injection of T. castaneum with either TcABCE-3A- or TcABCF-2A-specific dsRNA leads to a lethal phenotype [20].

\subsection{The ABCG Subfamily}

ABCG transporters are typical HTs, which must form homo- or heterodimers to fulfill their transport function. Compared with other half-transporter proteins, ABCG transporters have a reverse domain structure; its TMD is connected to the C-terminal region of NBD [14]. Some ABCG proteins can form dimers with different partners, thus increasing the repertoire of substrates they can transport [11]. The number of $A B C G$ genes in an insect species ranges from 2 to 24 . The white proteins of $D$. melanogaster can form dimers with one of the other two HTs named Brown and Scarlet and play a crucial role in the cellular uptake of pigment precursors in the eye [80]. An ortholog of the white gene of D. melanogaster is present in all known insect genomes, but the brown and scarlet genes are only present in some insects [11]. A study of the white ortholog of T. castaneum found that the transport precursor of a pigment across the membrane of Malpighian tubule cells is ABCG-dependent [20]. White is also necessary for the transport of uric acid in the larval epidermis of B. mori. The ABCG HTs homologous to brown in aphids, lepidopteran and hymenopteran species can form dimers with white to participate in the transport of urate [81]. In the B. mori genome, white and scarlet are juxtaposed in a head-to-tail orientation, which indicates that the origin of white and scarlet resulted from the tandem duplication of 
an ancestral gene. The same arrangement was also found in other insect species that lack a functional ortholog of the brown gene [19].

\subsection{The ABCH Subfamily}

$\mathrm{ABCH}$ transporters were first found in D. melanogaster, then in other insects; they have not been found in mammals, plants, fungi and C. elegans $[1,82,83]$. However, this type of $\mathrm{ABCH}$ protein was reported in zebrafish [84], but reports of the gene in other teleost fishes have not been consistent $[85,86]$. Four $A B C H$ genes were identified in the Ptychadena nana genome [87]. Similar to the ABCG transporter, $\mathrm{ABCH}$ proteins are also HTs and have the reverse domain organization with the NBD connecting to the N-terminal side of the TMD [14]. Three ABCH proteins exist in most of the known insect genomes. Although this protein is very similar to the ABCG transporter, little is known about its function at present. Silencing of the $A B C H 1$ gene of $P$. xylostella with a high dose of dsRNA results in lethal larval and pupal phenotypes [59]; thus $A B C H 1$ may be an excellent target for pest control. Injection of dsRNA of TcABCH-9C causes dehydration and death of T. castaneum larvae [20]. ABCH-9C may be involved in the formation of the protective lipid barrier on the cuticle surface of Locusta migratoria $[88,89]$ and D. melanogaster [89].

\section{ABC Transporters in Xenobiotic Detoxification by Insects}

\subsection{Insecticide Transport and Detoxification}

Generally, insect resistance to xenobiotics is due to point mutations at target sites, or the effective metabolism or sequestration of toxic substances $[90,91]$. The emergence of insecticide resistance in insects is mainly related to the decreased sensitivity of target sites to insecticides and changes in the expression or properties of metabolic detoxification genes [92,93]. Several members of the insect $\mathrm{ABC}$ transporter superfamily play a very important role in pesticide resistance by inhibiting the accumulation of intracellular pesticides and their metabolites [94].

Xenobiotic transcription factors (XTFs) are also important in regulating the expression of genes that encode proteins involved in detoxification. Cap'n'collar (Cnc) transcription factors are members of the XTF superfamily $[95,96]$. In the red flour beetle (T. castaneum), the Cap'n'collar C isoform (CncC) is involved in all three phases of insecticide detoxification and regulates the expression of $A B C A-U B$, $A B C A-1 A$ and $A B C A-1 A L$. RNAi and an insecticide bioassay showed that these $A B C A$ genes contributed to the susceptibility of T. castaneum to pyrethroid [97]. This study provided a clearer understanding of the role of $A B C$ transporter and its upstream regulatory pathway in insecticide detoxification.

Among $\mathrm{ABC}$ transporters family, the ABCB subfamily mostly represents the P-gps and multiple drug resistance (Mdr) proteins. P-gps are ATP-dependent efflux pumps, which are closely related to the transmembrane transport of substances. Some of these proteins are associated with multidrug resistance [98]. When RNAi-mediated gene silencing was used to analyze the potential function of P-gp in insecticide efflux in Aedes aegypti, temephos toxicity significantly increased (57\%) in the $P$-gp-silenced mutant [99]. Jin et al. reported that inhibition of P-gp increased the susceptibility of H. armigera to abamectin and indoxacarb [62]. Previous studies by Aurade et al. have also shown that $\mathrm{P}$-gp is associated with resistance of $H$. armigera to insecticides [100]. An increase in P-gp expression in D. melanogaster is directly related to abamectin resistance, and the level of P-gp in blood-brain barrier of resistant D. melanogaster is significantly higher than in the susceptible control [101,102]. In-depth analysis showed that P-gp content is regulated by epidermal growth factor receptor (EGFR) and protein kinase B (Akt, PKB) pathways in D. melanogaster [101]. Over-expression of $A B C B 4$ through gene amplification has been detected in pyrethroid-resistant Ae. aegypti [21]. ABCB transporter subfamily members Mdr49, Mdr50 and Mdr65 are associated with DDT resistance in 91-R strain of D. melanogaster. Among them, the resistance conferred by Mdr49 was related to its splice-form variant and amino acid residue changes [103,104]. D. melanogaster with a Mdr65-gene knockout via CRISPR/cas9 had increased susceptibility to all neuroactive insecticides tested. Deficiency crosses, synergism with 
the $\mathrm{ABC}$ inhibitor verapamil and accumulation of pesticides in the $M d r 65-$ knockout individuals further confirmed that Mdr65 plays an important role in pesticide transport [105]. Tissue-specific RNAi of Mdr65 also confirmed the role of the gene in reduced toxicity of multiple insecticides in D. melanogaster [106].

Many ABCC transporters can specifically transport a variety of drugs, so they are also called multidrug resistance proteins (MRPs). TrnMRP1 and TrnMRP4 are highly expressed in the Malpighian tubules in the lepidopteran Trichoplusia $n i$ and may be involved in excreting metabolic wastes or ingested xenobiotics [107]. Microarray studies of adult B. tabaci showed that an ABC transporter of subfamily $G$ is upregulated when exposed to thiamethoxam $[108,109]$. Compared with expression in susceptible strains, the expression of A, C, G, H and F subfamily members of ABC transporters was higher in chlorpyrifos- and fluronitrile-resistant strains of $P$. xylostella (diamondback moth), suggesting that these $\mathrm{ABC}$ transporters may be related to the transport or detoxification of different pesticides [110,111]. The expression of ABC genes HaOG200303 from subfamily C, HaOG200310, $\mathrm{HaOG} 200353$ and $\mathrm{HaOG} 200354$ from subfamily $\mathrm{G}$ and $\mathrm{HaOG} 200341$ from subfamily $\mathrm{H}$ were significantly upregulated in H. armigera when treated with both lambda-cyhalothrin and indoxacarb [62]. However, whether the high expression of $A B C$ transporter after insecticide induction is related to the detoxification metabolism of insects needs to be confirmed by further studies. PhABCC4 of Pediculus humanus humanus expressed in Xenopus oocytes functioned in ivermectin efflux, suggesting that PhABCC4 might be involved in ivermectin transport [112].

\subsection{Detoxification of Plant Secondary Metabolites}

Plants can release a variety of toxic secondary metabolites to deter the feeding of herbivorous insects, and insects have evolved corresponding countermeasures via natural selection, specialization, sequestration during the long-term interactions between plants and insects [113]. As part of these countermeasures, members of $\mathrm{ABC}$ transporter family play a crucial role in overcoming multiple chemical plant defenses. A gene knockout and bioassay in D. melanogaster indicates that Mdr is involved in the detoxification of plant secondary metabolite cardenolides [114]. A study of the ABC transporter C $p$ MRP (ABC subfamily $\mathrm{C}$ ) of $C$. populi revealed that $C p \mathrm{MRP}$ acts as a pacemaker, transporting specific metabolites from the hemolymph to defensive secretions, and eventually excreting them from the body. Silencing of $C p M R P$ makes larvae defenseless, indicating C $p$ MRP plays a key role in secretion [115]. Homologous sequences of $C p M R P$ were also identified in the defensive glands of two related leaf beetle species, suggesting that this $\mathrm{ABC}$ transporter is the key component of insect resistance to noxious phytochemicals.

The expression level of $A B C$ genes was studied in tissues of 5th instar larvae of H. armigera after they were fed an artificial diet supplemented with various plant secondary metabolites. Taxol induced the expression of $A B C E 1$ in Malpighian tubules, upregulated the expression of $A B C B 1$ in the gut and expression of $A B C B 1, A B C C 2$ and $A B C C 6$ in the rest of the body [61]. ABCB1 has also been shown to be associated with paclitaxel resistance of human cancer cells [116]. The expression of HaABCG11 was upregulated after larvae were fed a diet supplemented with nicotine compared to the control samples, and $H a A B C B 3$ expression was very high in the gut of $H$. armigera larvae after they fed on a diet containing nicotine or tomatine [61]. Similarly, $A B C B 3$ was upregulated in Manduca sexta larvae that fed on Datura and Solanum. This plant-specific expression pattern may be related to the adaptability of insect to these plants [117]. The function of ABCB3 in insects is not completely understood, but it most likely is important in a defense response of insects to plant secondary metabolites.

\section{ABC Transporter Roles in Bt Insecticidal Activity}

The ABC transporters that act as Bt-toxin receptor belong to subfamilies A, B, C and D (Table 2). With the long-term cultivation of Bt cotton, field resistance to Cry2Ab toxin evolved in H. armigera. The resistance of two $H$. armigera strains to $\mathrm{Cry} 2 \mathrm{Ab}$ was an independent evolutionary event involving different deletion mutations, which were located in different exons of the same $A B C A 2$ gene [68]. 
A homologous deletion in $\mathrm{HaABCA} 2$ was also detected in resistant lines of $\mathrm{H}$. punctigera Cry2Ab. A similar situation was also found in resistant lines of Pectinophora gossypiella; a loss of PgABCA2 exon 6 was caused by alternative splicing in resistant larvae of laboratory-selected strains in Arizona and field-selected strains in India [118]. In addition, insect ABCA2 was expressed in the midgut where the Cry2Ab toxin binds [68,119]. A bioassay of two strains of $H$. armigera with CRISPR/cas9 knockout of $H a A B C A 2$ showed that $H a A B C A 2$ plays an important role in mediating resistance to Cry2Aa and Cry2Ab [120].

Table 2. Bt toxins and their possible corresponding ABC transporters as receptors in insects.

\begin{tabular}{cccc}
\hline Bt toxin & Receptor & Target pest & Reference \\
\hline Cry1Aa & ABCC2 & Bombyx mori & {$[121]$} \\
Cry1Ab & ABCC2 & Bombyx mori & {$[122]$} \\
& ABCG1 & Ostrinia furnacalis & {$[123]$} \\
Cry1Ac & HBClicoverpa armigera & {$[25]$} \\
& ABCC2 & Heliothis virescens & {$[124]$} \\
& ABCG1 & Ostrinia furnacalis & {$[123]$} \\
& ABCG1 & Plutella xylostella & {$[125]$} \\
& ABCC2 & Plutella xylostella & {$[126]$} \\
& ABCC2 & Spodoptera exigua & {$[127]$} \\
Cry1Ca & ABCC3 & Spodoptera frugiperda & {$[128]$} \\
Cry1Fa & SBCC2 & Spodoptera exigua & {$[127]$} \\
Cry2Aa & ABCC2 & Helicovia nubilalis & {$[129]$} \\
Cry2Ab & ABCA2 & Helicoverpa armigera & {$[120]$} \\
& ABCA2 & Helicoverpa punctigera & {$[68]$} \\
& ABCA2 & Pectinophora gossypiella & {$[68]$} \\
Cry3Aa & ABCA2 & Chrysomela tremuela & {$[118]$} \\
Cry3Bb1 & ABCB1 & Diabrotica virgifera virgifera & {$[130]$} \\
\hline
\end{tabular}

A Chrysomela tremuela strain survived and reproduced on transgenic poplar trees that expressed a high level of Cry3Aa Bt toxin, and its Cry3Aa resistance was an autosomal recessive trait. Candidate resistance genes were analyzed using midgut transcriptome of larvae, demonstrating that a mutation of the $A B C B$ homolog of $P$ - $g p$ was closely linked to the resistance of Cry3Aa, and named CtABCB1. A 4-bp deletion in CtABCB1 introduced a frame shift with a premature stop codon, resulting in the loss of transporter signature motifs 1 (TpM1) and transmembrane domain 2 (TMD2) [130]. A CtABCB1 homologous gene in western corn rootworm (Diabrotica virgifera virgifera) was also shown to be genetically linked to Cry3Bb1 resistance [131]. Perhaps the insect ABCB1 transporter is a receptor specific for Cry3 toxin, and structural changes in this transporter may be associated with Cry3 toxin resistance of the insect.

Some ABCC transporters are a functional receptor for more than one Cry1A toxin. The binding of Cry1Ac toxin to ABCC2 on membrane vesicles can lead to membrane perforation. Bretschneider et al. studied the relationship between the $\mathrm{ABCC} 2$ of Heliothis virescens and cytotoxicity of three Cry1A toxins (Cry1Aa, Cry1Ab, Cry1Ac) in Spodoptera frugiperda Sf9 cells and found that ABCC2 is the central target of Cry1A toxin action [132]. Heterologous expression in D. melanogaster has been used to validate the involvement of ABCC2 in Cry1Ac toxin binding [133]. An inactivating mutation, such as mis-splicing of $A B C C 2$ or a mutation causing a single amino acid change, could reduce binding of Cry1Ac toxin, conferring high levels of Bt resistance in the target pest $[25,124,134]$. In a Cry1Ac-resistant strain of P. xylostella with a 30-bp deletion in exon 20, was expected to cause the removal of the 12th transmembrane (TM) domain and carboxyl terminal of TM12 that is located outside the cell. The mutation may result in the lack of function of a core ATP-binding loop [126]. In addition, an ABCC transporter is also the receptor of Cry1Ca and Cry1Fa toxins [127,129]. A cytotoxicity assay showed that the binding affinity of ABCC transporters to Cry toxin was largely linked to the susceptibility of receptor-expressing cells to Cry toxin and that the extracellular loop (ECL) structures determine the specificity of $\mathrm{ABCC}$ to Cry toxins [135]. 
Bt resistance mediated by ABCC transporters involves not only different forms of gene mutations, but also the regulation of $A B C C$ gene expression. The study of Bt resistance in hybrid larvae of B. mori revealed a trans-regulatory mechanism involved in the allele-specific expression of $A B C C 2$ in response to $\mathrm{Cry} 1 \mathrm{Ab}$ toxin, which may play an important role in insect Bt resistance [122]. The binding of Cry1Ac toxin to ABCC transporters that causes midgut membrane perforation is regulated by a constitutively and transcriptionally activated upstream gene (MAP4K4) in the MAPK signaling pathway [125]. In addition, Forkhead box protein A (FOXA) upregulates expression of $A B C C 2$ and $A B C C 3$ genes in $\mathrm{Sf} 9$ cells [128]. $\mathrm{ABCC} 2$ and $\mathrm{ABCC} 3$ are important receptors of Cry1Ac toxin, and their expression level has a significant influence on insect $\mathrm{Bt}$ resistance; thus, FOXA may be involved in the regulation of insect resistance to Cry1Ac toxin.

ABCG1 (white) gene is one of the most widely studied members of the ABCG protein subfamily. The white protein in P. xylostella is located on the cell membrane, and the expression of Pxwhite gene in the midgut of a Bt-resistant population is significantly lower than in a susceptible population. After RNAi silencing of the midgut Pxwhite gene, the sensitivity of the larvae to Bt-Cry1Ac toxin significantly decreased [136]. Genetic linkage analysis confirmed that the decrease was closely linked to the Bt-Cry1Ac resistance of the moth. Downregulated expression of ABCG subfamily genes in Ostrinia furnacalis is also related to its resistance to Cry1 Ab and Cry1Actoxins [123].

\section{Discussion}

Functional study of insect $A B C$ transporters and their role in resistance to chemical insecticides and $\mathrm{Bt}$ toxins has shown that several $\mathrm{ABC}$ transporters are involved in toxin resistance. However, more progress is needed to fully understand the functions and detailed mechanisms of action. Different $\mathrm{ABC}$ transporters may recognize different chemicals or Bt toxins, and their TMDs have distinct binding sites that recognize substrates with highly diverse chemical properties [137]. ABCA2 is the receptor of Cry2Ab toxin $[68,118,119], A B C B 1$ is the receptor of Cry3 toxin [130,131], and members of the ABCC family are receptors of Cry1 toxin $[25,124,132,134]$. Thus, different pesticides, toxic secondary metabolites of plants and Bt toxins may be recognized and transported by different $A B C$ transporters. The strategies and methods that are used to study human $\mathrm{ABC}$ transporters involved in drug transport can also be used to investigate $\mathrm{ABC}$ transporter functions and mechanisms involved in insect resistance. The sequencing of insect genomes provides unparalleled advantages over traditional methods for revealing the molecular basis and mechanisms of insect resistance to pesticides and $\mathrm{Bt}$ toxins, and insect genomics approaches will become the most important methods to analyze insect resistance mechanism.

$\mathrm{ABC}$ transporters are the main receptors for most $\mathrm{Bt}$ toxins, so it is not surprising that $\mathrm{Bt}$ resistance in pests is commonly related to a mutation in an $A B C$ transporter. Upstream regulatory factors such as MAP4K4 and FOXA can also change gene expression for ABC transporters, thereby altering susceptibility of pests to Bt toxins $[125,128]$. The regulatory pathways and corresponding mechanisms that affect the expression of $\mathrm{ABC}$ transporter need to be further elucidated. If the regulation mechanism of the expression of $A B C$ transporter can be clearly understood, more efficient and convenient measures can be developed for Bt resistance control. Insects that are resistant to chemical pesticides, plant toxic secondary metabolites and Bt toxins may also be subject to a fitness cost. Any such physiological cost correlated with resistance may also provide a target for pest control.

Plant-mediated RNA interference provides a new method and model for pest control in the field. The dsRNA fragment targeting the $\beta$-actin gene in Colorado potato beetle was transferred to potato chloroplasts, and the transgenic plants were lethal to Colorado potato beetle larvae [138]. The use of dsRNA to knockdown the acetylcholinesterase (AChE) gene involved in neuronal transmission and the ecdysone receptor $(E c R)$ gene involved in transcriptional activation of development in transgenic plants can effectively control whitefly populations [139]. Because insect resistance to chemical pesticides is related to the upregulation of certain $A B C$ transporters, silencing the genes for these $A B C$ transporters is expected to make the pest more susceptible to the pesticide. In addition, the development of inhibitors specific for a particular ABC transporter might enhance the susceptibility of the target insect. Since 
$\mathrm{ABC}$ transporters can differ significantly among various species, the inhibitor must be highly specific for the transporter involved in the target(s) species and not adversely affect other insects or organisms.

With the deepening of our knowledge on the structure and physiological function of insect $A B C$ transporters, the mechanism of action of these transporters in pesticide resistance, Bt insecticidal activity and other physiological processes will become clearer, and new technologies will be developed for the effective control of insect pests.

Supplementary Materials: Supplementary materials can be found at http://www.mdpi.com/1422-0067/20/11/ 2829/s1.

Author Contributions: Conception and literature review: C.W., S.C., M.J., K.L. and Y.X. Manuscript writing: C.W., S.C. and Y.X.

Funding: This work was supported by Key Project for Breeding Genetic Modified Organisms (No. 2016ZX08012004-003); National Natural Science Foundation of China (No. 31601646); Special Funds for Industrial Development of Dapeng New District, Shenzhen City (No. KY20180216) and Dapeng New District Industry Development Funds (No. KY20180115).

Conflicts of Interest: The authors declare no conflicts of interest.

\section{References}

1. Dean, M.; Rzhetsky, A.; Allikmets, R. The human ATP-binding cassette (ABC) transporter superfamily. Genome Res. 2001, 11, 1156-1166. [CrossRef] [PubMed]

2. Dassa, E.; Bouige, P. The ABC of ABCS: A phylogenetic and functional classification of $A B C$ systems in living organisms. Res. Microbiol. 2001, 152, 211-229. [CrossRef]

3. Holland, I.B.; Cole, S.P.; Kuchler, K.; Higgins, C.F. ABC Proteins—From Bacteria to Man; Academic Press: Cambridge, MA, USA, 2003; p. 647.

4. Berger, E.A. Different mechanisms of energy coupling for the active transport of proline and glutamine in Escherichia coli. Proc. Natl. Acad. Sci. USA 1973, 70, 1514-1518. [CrossRef] [PubMed]

5. Berger, E.A.; Heppel, L.A. Different mechanisms of energy coupling for the shock-sensitive and shock-resistant amino acid permeases of Escherichia coli. J. Biol. Chem. 1974, 249, 7747-7755. [PubMed]

6. Higgins, C.F.; Haag, P.D.; Nikaido, K.; Ardeshir, F.; Garcia, G.; Ames, G.F. Complete nucleotide sequence and identification of membrane components of the histidine transport operon of S. typhimurium. Nature 1982, 298, 723-727. [CrossRef] [PubMed]

7. Gilson, E.; Higgins, C.F.; Hofnung, M.; Ames, F.L.; Nikaido, H. Extensive homology between membrane-associated components of histidine and maltose transport systems of Salmonella typhimurium and Escherichia coli. J. Biol. Chem. 1982, 257, 9915.

8. Juliano, R.L.; Ling, V. A surface glycoprotein modulating drug permeability in Chinese hamster ovary cell mutants. Biochim. Biophys. Acta 1976, 455, 152-162. [CrossRef]

9. Riordan, J.R.; Deuchars, K.; Kartner, N.; Alon, N.; Trent, J.; Ling, V. Amplification of P-glycoprotein genes in multidrug-resistant mammalian cell lines. Nature 1985, 316, 817-819. [CrossRef]

10. Hyde, S.C.; Emsley, P.; Hartshorn, M.J.; Mimmack, M.M.; Gileadi, U.; Pearce, S.R.; Gallagher, M.P.; Gill, D.R.; Hubbard, R.E.; Higgins, C.F. Structural model of ATP-binding proteing associated with cystic fibrosis, multidrug resistance and bacterial transport. Nature 1990, 346, 362-365. [CrossRef]

11. Merzendorfer, $\mathrm{H}$. Chapter one-ABC transporters and their role in protecting insects from pesticides and their metabolites. Adv. Insect Physiol. 2014, 46, 1-72.

12. Rees, D.C.; Johnson, E.; Lewinson, O. ABC transporters: The power to change. Nat. Rev. Mol. Cell Biol. 2009, 10, 218-227. [CrossRef] [PubMed]

13. Higgins, C.F. ABC transporters: From microorganisms to man. Annu. Rev. Cell Biol. 1991, 8, 67-113. [CrossRef] [PubMed]

14. Dermauw, W.; Van Leeuwen, $\mathrm{T}$. The ABC gene family in arthropods: Comparative genomics and role in insecticide transport and resistance. Insect Biochem. Mol. Biol. 2014, 45, 89-110. [CrossRef] [PubMed]

15. Hopfner, K.P. Invited review: Architectures and mechanisms of ATP binding cassette proteins. Biopolymers 2016, 105, 492-504. [CrossRef] [PubMed] 
16. Kartner, N.; Evernden-Porelle, D.; Bradley, G.; Ling, V. Detection of P-glycoprotein in multidrug-resistant cell lines by monoclonal antibodies. Nature 1985, 316, 820-823. [CrossRef] [PubMed]

17. Lage, H. ABC-transporters: Implications on drug resistance from microorganisms to human cancers. Int. J. Antimicrob. Agents 2003, 22, 188-199. [CrossRef]

18. Ewart, G.D.; Howells, A.J. ABC transporters involved in transport of eye pigment precursors in Drosophila melanogaster. Methods Enzymol. 1998, 292, 213-224.

19. Tatematsu, K.; Yamamoto, K.; Uchino, K.; Narukawa, J.; Iizuka, T.; Banno, Y.; Katsuma, S.; Shimada, T.; Tamura, T.; Sezutsu, H.; et al. Positional cloning of silkworm white egg 2 (w-2) locus shows functional conservation and diversification of $\mathrm{ABC}$ transporters for pigmentation in insects. Genes Cells 2011, 16, 331-342. [CrossRef]

20. Broehan, G.; Kroeger, T.; Lorenzen, M.; Merzendorfer, H. Functional analysis of the ATP-binding cassette (ABC) transporter gene family of Tribolium castaneum. BMC Genom. 2013, 14, 6. [CrossRef]

21. Bariami, V.; Jones, C.M.; Poupardin, R.; Vontas, J.; Ranson, H. Gene amplification, ABC transporters and cytochrome P450s: Unraveling the molecular basis of pyrethroid resistance in the dengue vector, Aedes aegypti. PLoS Neglect. Trop. Dis. 2012, 6, e1692. [CrossRef]

22. Bonizzoni, M.; Afrane, Y.; Dunn, W.A.; Atieli, F.K.; Zhou, G.; Zhong, D.; Li, J.; Githeko, A.; Yan, G. Comparative transcriptome analyses of deltamethrin-resistant and -susceptible Anopheles gambiae mosquitoes from Kenya by RNA-Seq. PLoS ONE 2012, 7, e44607. [CrossRef] [PubMed]

23. Mamidala, P.; Wijeratne, A.J.; Wijeratne, S.; Kornacker, K.; Sudhamalla, B.; Rivera-Vega, L.J.; Hoelmer, A.; Meulia, T.; Jones, S.C.; Mittapalli, O. RNA-Seq and molecular docking reveal multi-level pesticide resistance in the bed bug. BMC Genom. 2012, 13, 6. [CrossRef] [PubMed]

24. Pardo-López, L.; Soberón, M.; Bravo, A. Bacillus thuringiensis insecticidal three-domain Cry toxins: Mode of action, insect resistance and consequences for crop protection. FEMS Microbiol. Rev. 2012, 37, 3-22. [CrossRef] [PubMed]

25. Xiao, Y.; Zhang, T.; Liu, C.; Heckel, D.G.; Li, X.; Tabashnik, B.E.; Wu, K. Mis-splicing of the ABCC2 gene linked with Bt toxin resistance in Helicoverpa armigera. Sci. Rep. 2014, 4, 6184. [CrossRef] [PubMed]

26. Chen, L.; Wei, J.Z.; Liu, C.; Zhang, W.N.; Wang, B.J.; Niu, L.L.; Liang, G.M. Specific binding protein ABCC1 Is associated with Cry2Ab toxicity in Helicoverpa armigera. Front. Physiol. 2018, 9, 745. [CrossRef] [PubMed]

27. Heckel, D.G. Learning the ABCs of Bt: ABC transporters and insect resistance to Bacillus thuringiensis provide clues to a crucial step in toxin mode of action. Pestic. Biochem. Phys. 2012, 104, 103-110. [CrossRef]

28. Gott, R.C.; Kunkel, G.R.; Zobel, E.S.; Lovett, B.R.; Hawthorne, D.J. Implicating ABC transporters in insecticide resistance: Research strategies and a decision framework. J. Econ. Entomol. 2017, 110, 667-677. [CrossRef]

29. Chang, G.; Roth, C.B. Structure of MsbA from E. coli: A homolog of the multidrug resistance ATP binding cassette (ABC) transporters. Science 2001, 293, 1793-1800. [CrossRef]

30. Dawson, R.J.; Locher, K.P. Structure of a bacterial multidrug ABC transporter. Nature 2006, 443, $180-185$. [CrossRef]

31. Hvorup, R.N.; Goetz, B.A.; Niederer, M.; Hollenstein, K.; Perozo, E.; Locher, K.P. Asymmetry in the structure of the ABC transporter-binding protein complex BtuCD-BtuF. Science 2007, 317, 1387-1390. [CrossRef]

32. Ter Beek, J.; Guskov, A.; Slotboom, D.J. Structural diversity of ABC transporters. J. Gen. Physiol. 2014, 143, 419-435. [CrossRef] [PubMed]

33. Holland, I.B.; Blight, M.A. ABC-ATPases, adaptable energy generators fuelling transmembrane movement of a variety of molecules in organisms from bacteria to humans. J. Mol. Biol. 1999, 293, 381-399. [CrossRef] [PubMed]

34. Erkens, G.B.; Berntsson, R.P.; Fulyani, F.; Majsnerowska, M.; Vujicic-Zagar, A.; Ter Beek, J.; Poolman, B.; Slotboom, D.J. The structural basis of modularity in ECF-type ABC transporters. Nat. Struct. Mol. Biol. 2011, 18, 755-760. [CrossRef] [PubMed]

35. Xu, K.; Zhang, M.; Zhao, Q.; Yu, F.; Guo, H.; Wang, C.; He, F.; Ding, J.; Zhang, P. Crystal structure of a folate energy-coupling factor transporter from Lactobacillus brevis. Nature 2013, 497, 268-271. [CrossRef] [PubMed]

36. Eitinger, T.; Rodionov, D.A.; Grote, M.; Schneider, E. Canonical and ECF-type ATP-binding cassette importers in prokaryotes: Diversity in modular organization and cellular functions. FEMS Microbiol. Rev. 2015, 35, 3-67. [CrossRef] [PubMed]

37. Wang, T.; Fu, G.; Pan, X.; Wu, J.; Gong, X.; Wang, J.; Shi, Y. Structure of a bacterial energy-coupling factor transporter. Sci. Found. China 2014, 497, 272-276. [CrossRef] [PubMed] 
38. Gottesman, M.M.; Ambudkar, S.V. Overview: ABC transporters and human disease. J. Bioenerg. Biomembr. 2001, 33, 453-458. [CrossRef] [PubMed]

39. Higgins, C.F.; Linton, K.J. The ATP switch model for ABC transporters. Nat. Struct Mol. Biol. 2004, 11, 918-926. [CrossRef] [PubMed]

40. Senior, A.E.; al-Shawi, M.K.; Urbatsch, I.L. The catalytic cycle of P-glycoprotein. FEBS Lett. 1995, 377, 285-289.

41. Sauna, Z.E.; Kim, I.W.; Nandigama, K.; Kopp, S.; Chiba, P.; Ambudkar, S.V. Catalytic cycle of ATP hydrolysis by P-glycoprotein: Evidence for formation of the E.S reaction intermediate with ATP-gamma-S, a nonhydrolyzable analogue of ATP. Biochemistry 2007, 46, 13787-13799. [CrossRef]

42. Siarheyeva, A.; Liu, R.; Sharom, F.J. Characterization of an asymmetric occluded state of P-glycoprotein with two bound nucleotides: Implications for catalysis. J. Biol. Chem. 2010, 285, 7575-7586. [CrossRef] [PubMed]

43. Zhang, X.C.; Han, L.; Zhao, Y. Thermodynamics of ABC transporters. Protein Cell 2016, 7, 17-27. [CrossRef] [PubMed]

44. George, A.M.; Jones, P.M. Perspectives on the structure-function of ABC transporters: The switch and constant contact models. Prog. Biophys. Mol. Biol. 2012, 109, 95-107. [CrossRef] [PubMed]

45. Linton, K.J.; Higgins, C.F. Structure and function of ABC transporters: The ATP switch provides flexible control. Pflugers Arch. 2007, 453, 555-567. [CrossRef] [PubMed]

46. Deeley, R.G.; Westlake, C.; Cole, S.P. Transmembrane transport of endo- and xenobiotics by mammalian ATP-binding cassette multidrug resistance proteins. Physiol. Rev. 2006, 86, 849-899. [CrossRef] [PubMed]

47. Roth, C.W.; Holm, I.; Graille, M.; Dehoux, P.; Rzhetsky, A.; Wincker, P.; Weissenbach, J.; Brey, P.T. Identification of the Anopheles gambiae ATP-binding cassette transporter superfamily genes. Mol. Cells 2003, 15, 150-158.

48. Sturm, A.; Cunningham, P.; Dean, M. The ABC transporter gene family of Daphnia pulex. BMC Genom. 2009, 10, 170. [CrossRef]

49. Lee, S.H.; Kang, J.S.; Min, J.S.; Yoon, K.S.; Strycharz, J.P.; Johnson, R.; Mittapalli, O.; Margam, V.M.; Sun, W.; Li, H.M.; et al. Decreased detoxification genes and genome size make the human body louse an efficient model to study xenobiotic metabolism. Insect Mol. Biol. 2010, 19, 599-615. [CrossRef]

50. Liu, S.; Zhou, S.; Tian, L.; Guo, E.; Luan, Y.; Zhang, J.; Li, S. Genome-wide identification and characterization of ATP-binding cassette transporters in the silkworm, Bombyx mori. BMC Genom. 2011, 12, 491. [CrossRef]

51. Xie, X.; Cheng, T.; Wang, G.; Duan, J.; Niu, W.; Xia, Q. Genome-wide analysis of the ATP-binding cassette (ABC) transporter gene family in the silkworm, Bombyx mori. Mol. Biol Rep. 2012, 39, 7281-7291. [CrossRef]

52. Pearce, S.; Clarke, D.; East, P.; Elfekih, S.; Gordon, K.; Jermiin, L.; McGaughran, A.; Oakeshott, J.; Papanikolaou, A.; Perera, O. Genomic innovations, transcriptional plasticity and gene loss underlying the evolution and divergence of two highly polyphagous and invasive Helicoverpa pest species. BMC Biol. 2017, 15, 63. [CrossRef] [PubMed]

53. Dermauw, W.; Osborne, E.J.; Clark, R.M.; Grbic, M.; Tirry, L.; Van Leeuwen, T. A burst of ABC genes in the genome of the polyphagous spider mite Tetranychus urticae. BMC Genom. 2013, 14, 317. [CrossRef] [PubMed]

54. Strauss, A.S.; Wang, D.; Stock, M.; Gretscher, R.R.; Groth, M.; Boland, W.; Burse, A. Tissue-specific transcript profiling for $\mathrm{ABC}$ transporters in the sequestering larvae of the phytophagous leaf beetle Chrysomela populi. PLoS ONE 2014, 9, e98637. [CrossRef] [PubMed]

55. Hull, J.J.; Chaney, K.; Geib, S.M.; Fabrick, J.A.; Brent, C.S.; Walsh, D.; Lavine, L.C. Transcriptome-based identification of ABC transporters in the western tarnished plant bug Lygus hesperus. PLoS ONE 2014, 9, e113046. [CrossRef]

56. Carmona-Antonanzas, G.; Carmichael, S.N.; Heumann, J.; Taggart, J.B.; Gharbi, K.; Bron, J.E.; Bekaert, M.; Sturm, A. A Survey of the ATP-binding cassette (ABC) gene superfamily in the salmon louse (Lepeophtheirus salmonis). PLoS ONE 2015, 10, e0137394. [CrossRef]

57. Sun, H.; Pu, J.; Chen, F.; Wang, J.; Han, Z. Multiple ATP-binding cassette transporters are involved in insecticide resistance in the small brown planthopper, Laodelphax striatellus. Insect Mol. Biol. 2017, 26, 343-355. [CrossRef]

58. Tian, L.; Song, T.; He, R.; Yang, Z.; Xie, W.; Wu, Q.; Wang, S.; Zhou, X.; Zhang, Y.J.B.G. Genome-wide analysis of ATP-binding cassette (ABC) transporters in the sweetpotato whitefly, Bemisia tabaci. BMC Genom. 2017, 18, 330. [CrossRef] 
59. Guo, Z.J.; Kang, S.; Zhu, X.; Xia, J.X.; Wu, Q.J.; Wang, S.L.; Xie, W.; Zhang, Y.J. The novel ABC transporter $\mathrm{ABCH} 1$ is a potential target for RNAi-based insect pest control and resistance management. Sci. Rep. 2015, 5, 13728. [CrossRef]

60. Qi, W.; Ma, X.; He, W.; Chen, W.; Zou, M.; Gurr, G.M.; Vasseur, L.; You, M. Characterization and expression profiling of ATP-binding cassette transporter genes in the diamondback moth, Plutella xylostella (L.). BMC Genom. 2016, 17, 760. [CrossRef]

61. Bretschneider, A.; Heckel, D.G.; Vogel, H. Know your ABCs: Characterization and gene expression dynamics of ABC transporters in the polyphagous herbivore Helicoverpa armigera. Insect Biochem. Mol. Biol. 2016, 72, 1-9. [CrossRef]

62. Jin, M.; Liao, C.; Chakrabarty, S.; Zheng, W.; Wu, K.; Xiao, Y. Transcriptional response of ATP-binding cassette (ABC) transporters to insecticides in the cotton bollworm, Helicoverpa armigera. Pestic. Biochem. Phys. 2019, 154, 46-59. [CrossRef] [PubMed]

63. Wang, X.H.; Fang, X.D.; Yang, P.C.; Jiang, X.T.; Jiang, F.; Zhao, D.J.; Li, B.L.; Cui, F.; Wei, J.N.; Ma, C.A.; et al. The locust genome provides insight into swarm formation and long-distance flight. Nat. Commun. 2014, 5, 1-9. [CrossRef] [PubMed]

64. Lu, H.; Xu, Y.; Cui, F. Phylogenetic analysis of the ATP-binding cassette transporter family in three mosquito species. Pestic. Biochem. Physiol. 2016, 132, 118-124. [CrossRef] [PubMed]

65. Quazi, F.; Molday, R.S. Lipid transport by mammalian ABC proteins. Essays Biochem. 2011, 50, $265-290$. [CrossRef] [PubMed]

66. Zhao, Z.; Zera, A.J. Differential lipid biosynthesis underlies a tradeoff between reproduction and flight capability in a wing-polymorphic cricket. Proc. Natl. Acad. Sci. USA 2002, 99, 16829-16834. [CrossRef]

67. Zera, A.J.; Zhao, Z. Effect of a juvenile hormone analogue on lipid metabolism in a wing-polymorphic cricket: Implications for the endocrine-biochemical bases of life-history trade-offs. Physiol. Biochem. Zool. 2004, 77, 255-266. [CrossRef]

68. Tay, W.T.; Mahon, R.J.; Heckel, D.G.; Walsh, T.K.; Downes, S.; James, W.J.; Lee, S.F.; Reineke, A.; Williams, A.K.; Gordon, K.H.J. Insect resistance to Bacillus thuringiensis toxin Cry2Ab is conferred by mutations in an ABC transporter subfamily a protein. PLoS Genet. 2015, 11, e1005534. [CrossRef] [PubMed]

69. Metzendorf, C.; Wu, W.; Lind, M.I. Overexpression of Drosophila mitoferrin in 1(2)mbn cells results in dysregulation of Fer1HCH expression. Biochem. J. 2009, 421, 463-471. [CrossRef]

70. Sooksa-Nguan, T.; Yakubov, B.; Kozlovskyy, V.I.; Barkume, C.M.; Howe, K.J.; Thannhauser, T.W.; Rutzke, M.A.; Hart, J.J.; Kochian, L.V.; Rea, P.A.; et al. Drosophila ABC transporter, DmHMT-1, confers tolerance to cadmium. DmHMT-1 and its yeast homolog, SpHMT-1, are not essential for vacuolar phytochelatin sequestration. J. Biol. Chem. 2009, 284, 354-362. [CrossRef]

71. Telonis-Scott, M.; Hallas, R.; McKechnie, S.W.; Wee, C.W.; Hoffmann, A.A. Selection for cold resistance alters gene transcript levels in Drosophila melanogaster. J. Insect Physiol. 2009, 55, 549-555. [CrossRef]

72. Petschenka, G.; Pick, C.; Wagschal, V.; Dobler, S. Functional evidence for physiological mechanisms to circumvent neurotoxicity of cardenolides in an adapted and a non-adapted hawk-moth species. Proc. Biol. Sci. 2013, 280, 20123089. [CrossRef] [PubMed]

73. Wanders, R.J.; Visser, W.F.; van Roermund, C.W.; Kemp, S.; Waterham, H.R. The peroxisomal ABC transporter family. Pflug. Arch. 2007, 453, 719-734. [CrossRef] [PubMed]

74. Morita, M.; Imanaka, T. Peroxisomal ABC transporters: Structure, function and role in disease. Biochim. Biophys. Acta 2012, 1822, 1387-1396. [CrossRef] [PubMed]

75. Kerr, I.D. Sequence analysis of twin ATP binding cassette proteins involved in translational control, antibiotic resistance, and ribonuclease L inhibition. Biochem. Biophys. Res. Commun. 2004, 315, 166-173. [CrossRef] [PubMed]

76. Tyzack, J.K.; Wang, X.; Belsham, G.J.; Proud, C.G. ABC50 interacts with eukaryotic initiation factor 2 and associates with the ribosome in an ATP-dependent manner. J. Biol. Chem. 2000, 275, 34131-34139. [CrossRef] [PubMed]

77. Andersen, D.S.; Leevers, S.J. The essential Drosophila ATP-binding cassette domain protein, pixie, binds the $40 \mathrm{~S}$ ribosome in an ATP-dependent manner and is required for translation initiation. J. Biol. Chem. 2007, 282, 14752-14760. [CrossRef] 
78. Barthelme, D.; Dinkelaker, S.; Albers, S.V.; Londei, P.; Ermler, U.; Tampe, R. Ribosome recycling depends on a mechanistic link between the FeS cluster domain and a conformational switch of the twin-ATPase ABCE1. Proc. Natl. Acad. Sci. USA 2011, 108, 3228-3233. [CrossRef]

79. Bisbal, C.; Martinand, C.; Silhol, M.; Lebleu, B.; Salehzada, T. Cloning and characterization of a RNAse L inhibitor. A new component of the interferon-regulated 2-5A pathway. J. Biol. Chem. 1995, 270, 13308-13317. [CrossRef]

80. Mackenzie, S.M.; Brooker, M.R.; Gill, T.R.; Cox, G.B.; Howells, A.J.; Ewart, G.D. Mutations in the white gene of Drosophila melanogaster affecting ABC transporters that determine eye colouration. BBA Biomembr. 1999, 1419, 173-185. [CrossRef]

81. Wang, L.; Kiuchi, T.; Fujii, T.; Daimon, T.; Li, M.; Banno, Y.; Kikuta, S.; Kikawada, T.; Katsuma, S.; Shimada, T. Mutation of a novel ABC transporter gene is responsible for the failure to incorporate uric acid in the epidermis of ok mutants of the silkworm, Bombyx mori. Insect Biochem. Mol. Biol. 2013, 43, 562-571. [CrossRef]

82. Kovalchuk, A.; Driessen, A.J. Phylogenetic analysis of fungal ABC transporters. BMC Genom. 2010, 11, 177. [CrossRef] [PubMed]

83. Verrier, P.J.; Bird, D.; Burla, B.; Dassa, E.; Forestier, C.; Geisler, M.; Klein, M.; Kolukisaoglu, U.; Lee, Y.; Martinoia, E.; et al. Plant ABC proteins-A unified nomenclature and updated inventory. Trends Plant. Sci. 2008, 13, 151-159. [CrossRef] [PubMed]

84. Popovic, M.; Zaja, R.; Loncar, J.; Smital, T. A novel ABC transporter The first insight into zebrafish (Danio rerio) ABCH1. Mar. Environ. Res. 2010, 69, S11-S13. [CrossRef] [PubMed]

85. Liu, S.; Li, Q.; Liu, Z. Genome-wide identification, characterization and phylogenetic analysis of 50 catfish ATP-binding cassette (ABC) transporter genes. PLoS ONE 2013, 8, e63895. [CrossRef] [PubMed]

86. Dean, M.; Annilo, T. Evolution of the ATP-binding cassette (ABC) transporter superfamily in vertebrates. Annu. Rev. Genomics Hum. Genet. 2005, 6, 123-142. [CrossRef] [PubMed]

87. Jeong, C.B.; Kim, B.M.; Kang, H.M.; Choi, I.Y.; Rhee, J.S.; Lee, J.S. Marine medaka ATP-binding cassette (ABC) superfamily and new insight into teleost Abch nomenclature. Sci. Rep. 2015, 5, 15409. [CrossRef] [PubMed]

88. Yu, Z.; Wang, Y.; Zhao, X.; Liu, X.; Ma, E.; Moussian, B.; Zhang, J. The ABC transporter ABCH-9C is needed for cuticle barrier construction in Locusta migratoria. Insect Biochem. Mol. Biol. 2017, 87, 90-99. [CrossRef] [PubMed]

89. Zuber, R.; Norum, M.; Wang, Y.; Oehl, K.; Gehring, N.; Accardi, D.; Bartozsewski, S.; Berger, J.; Flotenmeyer, M.; Moussian, B. The ABC transporter Snu and the extracellular protein Snsl cooperate in the formation of the lipid-based inward and outward barrier in the skin of Drosophila. Eur. J. Cell Biol. 2018, 97, 90-101. [CrossRef]

90. Strycharz, J.P.; Lao, A.; Li, H.M.; Qiu, X.H.; Lee, S.H.; Sun, W.L.; Yoon, K.S.; Doherty, J.J.; Pittendrigh, B.R.; Clark, J.M. Resistance in the highly DDT-resistant 91-R strain of Drosophila melanogaster involves decreased penetration, increased metabolism, and direct excretion. Pestic. Biochem. Phys. 2013, 107, 207-217. [CrossRef]

91. Granada, Y.; Mejia-Jaramillo, A.M.; Strode, C.; Triana-Chavez, O. A point mutation V419L in the sodium channel gene from natural populations of Aedes aegypti is involved in resistance to lambda-cyhalothrin in Colombia. Insects 2018, 9, 23. [CrossRef]

92. Li, X.; Schuler, M.A.; Berenbaum, M.R. Molecular mechanisms of metabolic resistance to synthetic and natural xenobiotics. Annu. Rev. Entomol. 2007, 52, 231-253. [CrossRef] [PubMed]

93. Van, L.T.; Vontas, J.; Tsagkarakou, A.; Dermauw, W.; Tirry, L. Acaricide resistance mechanisms in the two-spotted spider mite Tetranychus urticae and other important Acari: A review. Insect Biochem. Mol. Biol. 2010, 40, 563-572.

94. Buss, D.S.; Callaghan, A. Interaction of pesticides with p-glycoprotein and other ABC proteins: A survey of the possible importance to insecticide, herbicide and fungicide resistance. Pestic. Biochem. Phys. 2008, 90, 141-153. [CrossRef]

95. Nakata, K.; Tanaka, Y.; Nakano, T.; Adachi, T.; Tanaka, H.; Kaminuma, T.; Ishikawa, T. Nuclear receptor-mediated transcriptional regulation in phase I, II, and III xenobiotic metabolizing systems. Drug Metab. Pharmacokinet. 2006, 21, 437-457. [CrossRef]

96. Sykiotis, G.P.; Bohmann, D. Stress-activated cap'n'collar transcription factors in aging and human disease. Sci. Signal. 2010, 3, re3. [CrossRef] [PubMed] 
97. Kalsi, M.; Palli, S.R. Cap n collar transcription factor regulates multiple genes coding for proteins involved in insecticide detoxification in the red flour beetle, Tribolium castaneum. Insect Biochem. Mol. Biol. 2017, 90, 43-52. [CrossRef] [PubMed]

98. Sharom, F.J. The P-glycoprotein multidrug transporter. Essays Biochem. 2011, 50, 161-178. [CrossRef]

99. Figueiramansur, J.; Ferreirapereira, A.; Mansur, J.F.; Franco, T.A.; Alvarenga, E.S.; Sorgine, M.H.; Neves, B.C.; Melo, A.C.; Leal, W.S.; Masuda, H. Silencing of P-glycoprotein increases mortality in temephos-treated Aedes aegypti larvae. Insect Mol. Biol. 2013, 22, 648-658. [CrossRef]

100. Aurade, R.M.; Jayalakshmi, S.K.; Sreeramulu, K. P-glycoprotein ATPase from the resistant pest, Helicoverpa armigera: Purification, characterization and effect of various insecticides on its transport function. Biochim. Biophys. Acta 2010, 1798, 1135-1143. [CrossRef]

101. Luo, L.; Sun, Y.J.; Wu, Y.J. Abamectin resistance in Drosophila is related to increased expression of P-glycoprotein via the dEGFR and dAkt pathways. Insect Biochem. Mol. Biol. 2013, 43, 627-634. [CrossRef]

102. Mayer, F.; Mayer, N.; Chinn, L.; Pinsonneault, R.L.; Kroetz, D.; Bainton, R.J. Evolutionary conservation of vertebrate blood-brain barrier chemoprotective mechanisms in Drosophila. J. Neurosci. 2009, 29, 3538-3550. [CrossRef] [PubMed]

103. Gellatly, K.J.; Yoon, K.S.; Doherty, J.J.; Sun, W.L.; Pittendrigh, B.R.; Clark, J.M. RNAi validation of resistance genes and their interactions in the highly DDT-resistant 91-R strain of Drosophila melanogaster. Pestic. Biochem. Phys. 2015, 121, 107-115. [CrossRef] [PubMed]

104. Seong, K.M.; Sun, W.; Clark, J.M.; Pittendrigh, B.R. Splice form variant and amino acid changes in MDR49 confers DDT resistance in transgenic Drosophila. Sci. Rep. 2016, 6, 23355. [CrossRef]

105. Denecke, S.; Fusetto, R.; Batterham, P. Describing the role of Drosophila melanogaster ABC transporters in insecticide biology using CRISPR-Cas9 knockouts. Insect Biochem. Mol. Biol. 2017, 91, 1-9. [CrossRef] [PubMed]

106. Sun, H.; Buchon, N.; Scott, J.G. Mdr65 decreases toxicity of multiple insecticides in Drosophila melanogaster. Insect Biochem. Mol. Biol. 2017, 89, 11-16. [CrossRef] [PubMed]

107. Labbe, R.; Caveney, S.; Donly, C. Expression of multidrug resistance proteins is localized principally to the Malpighian tubules in larvae of the cabbage looper moth, Trichoplusia ni. J. Exp. Biol. 2011, 214, 937-944. [CrossRef] [PubMed]

108. Yang, N.; Xie, W.; Jones, C.; Bass, C.; Jiao, X.; Yang, X.; Liu, B.; Li, R.; Zhang, Y. Transcriptome profiling of the whitefly Bemisia tabaci reveals stage-specific gene expression signatures for thiamethoxam resistance. Insect Mol. Biol. 2013, 22, 485-496. [CrossRef]

109. Yang, N.; Xie, W.; Yang, X.; Wang, S.L.; Wu, Q.J.; Li, R.M.; Pan, H.P.; Liu, B.M.; Shi, X.B.; Fang, Y.; et al. Transcriptomic and Proteomic Responses of Sweetpotato Whitefly, Bemisia tabaci, to Thiamethoxam. PLOS ONE 2013, 8, e61820. [CrossRef]

110. He, W.; You, M.; Vasseur, L.; Yang, G.; Xie, M.; Cui, K.; Bai, J.; Liu, C.; Li, X.; Xu, X.; et al. Developmental and insecticide-resistant insights from the de novo assembled transcriptome of the diamondback moth, Plutella xylostella. Genomics 2012, 99, 169-177. [CrossRef]

111. You, M.; Yue, Z.; He, W.; Yang, X.; Yang, G.; Xie, M.; Zhan, D.; Baxter, S.W.; Vasseur, L.; Gurr, G.M. A heterozygous moth genome provides insights into herbivory and detoxification. Nat. Genet. 2013, 45, 220-225. [CrossRef]

112. Kim, J.H.; Gellatly, K.J.; Lueke, B.; Kohler, M.; Nauen, R.; Murenzi, E.; Yoon, K.S.; Clark, J.M. Detoxification of ivermectin by ATP binding cassette transporter C4 and cytochrome P450 monooxygenase 6CJ1 in the human body louse, Pediculus humanus humanus. Insect Mol. Biol. 2018, 27, 73-82. [CrossRef] [PubMed]

113. Petschenka, G.; Agrawal, A.A. How herbivores coopt plant defenses: Natural selection, specialization, and sequestration. Curr. Opin. Insect Sci. 2016, 14, 17-24. [CrossRef] [PubMed]

114. Groen, S.C.; LaPlante, E.R.; Alexandre, N.M.; Agrawal, A.A.; Dobler, S.; Whiteman, N.K. Multidrug transporters and organic anion transporting polypeptides protect insects against the toxic effects of cardenolides. Insect Biochem. Mol. Biol. 2017, 81, 51-61. [CrossRef] [PubMed]

115. Strauss, A.S.; Peters, S.; Boland, W.; Burse, A. ABC transporter functions as a pacemaker for sequestration of plant glucosides in leaf beetles. Elife 2013, 2, e01096. [CrossRef]

116. Aldonza, M.B.; Hong, J.Y.; Lee, S.K. Paclitaxel-resistant cancer cell-derived secretomes elicit ABCB1-associated docetaxel cross-resistance and escape from apoptosis through FOXO3a-driven glycolytic regulation. Exp. Mol. Med. 2017, 49, e286. [CrossRef] [PubMed] 
117. Koenig, C.; Bretschneider, A.; Heckel, D.G.; Grosse-Wilde, E.; Hansson, B.S.; Vogel, H. The plastic response of Manduca sexta to host and non-host plants. Insect Biochem. Mol. Biol. 2015, 63, 72-85. [CrossRef] [PubMed]

118. Mathew, L.G.; Ponnuraj, J.; Mallappa, B.; Chowdary, L.R.; Zhang, J.; Tay, W.T.; Walsh, T.K.; Gordon, K.H.J.; Heckel, D.G.; Downes, S.; et al. ABC transporter mis-splicing associated with resistance to Bt toxin Cry2Ab in laboratory- and field-selected pink bollworm. Sci. Rep. 2018, 8, 13531. [CrossRef] [PubMed]

119. Tabashnik, B.E. ABCs of insect resistance to Bt. PLoS Genet. 2015, 11, e1005646. [CrossRef] [PubMed]

120. Wang, J.; Wang, H.; Liu, S.; Liu, L.; Tay, W.T.; Walsh, T.K.; Yang, Y.; Wu, Y. CRISPR/Cas9 mediated genome editing of Helicoverpa armigera with mutations of an ABC transporter gene HaABCA2 confers resistance to Bacillus thuringiensis Cry2A toxins. Insect Biochem. Mol. Biol. 2017, 87, 147-153. [CrossRef]

121. Tanaka, S.; Endo, H.; Adegawa, S.; Iizuka, A.; Imamura, K.; Kikuta, S.; Sato, R. Bombyx mori ABC transporter C2 structures responsible for the receptor function of Bacillus thuringiensis Cry1Aa toxin. Insect Biochem. Mol. Biol. 2017, 91, 44-54. [CrossRef] [PubMed]

122. Chen, Y.; Li, M.; Islam, I.; You, L.; Wang, Y.; Li, Z.; Ling, L.; Zeng, B.; Xu, J.; Huang, Y.; et al. Allelic-specific expression in relation to Bombyx mori resistance to Bt toxin. Insect Biochem Mol. Biol. 2014, 54, 53-60. [CrossRef] [PubMed]

123. Zhang, T.; Coates, B.S.; Wang, Y.; Wang, Y.; Bai, S.; Wang, Z.; He, K. Down-regulation of aminopeptidase N and $\mathrm{ABC}$ transporter subfamily $\mathrm{G}$ transcripts in Cry1Ab and Cry1Ac resistant Asian corn borer, Ostrinia furnacalis (Lepidoptera: Crambidae). Int. J. Biol. Sci. 2017, 13, 835-851. [CrossRef] [PubMed]

124. Gahan, L.J.; Pauchet, Y.; Vogel, H.; Heckel, D.G. An ABC Transporter Mutation Is Correlated with Insect Resistance to Bacillus thuringiensis Cry1Ac Toxin. PLoS Genet. 2010, 6, e1001248. [CrossRef] [PubMed]

125. Guo, Z.; Kang, S.; Chen, D.; Wu, Q.; Wang, S.; Xie, W.; Zhu, X.; Baxter, S.W.; Zhou, X.; Jurat-Fuentes, J.L.; et al. MAPK signaling pathway alters expression of midgut ALP and ABCC genes and causes resistance to Bacillus thuringiensis Cry1Ac toxin in diamondback moth. PLoS Genet. 2015, 11, e1005124. [CrossRef] [PubMed]

126. Baxter, S.W.; Badenes-Perez, F.R.; Morrison, A.; Vogel, H.; Crickmore, N.; Kain, W.; Wang, P.; Heckel, D.G.; Jiggins, C.D. Parallel evolution of Bacillus thuringiensis toxin resistance in Lepidoptera. Genetics 2011, 189, 675-679. [CrossRef] [PubMed]

127. Park, Y.; Gonzalez-Martinez, R.M.; Navarro-Cerrillo, G.; Chakroun, M.; Kim, Y.; Ziarsolo, P.; Blanca, J.; Canizares, J.; Ferre, J.; Herrero, S. ABCC transporters mediate insect resistance to multiple Bt toxins revealed by bulk segregant analysis. BMC Biol. 2014, 12, 46. [CrossRef]

128. Li, J.; Ma, Y.; Yuan, W.; Xiao, Y.; Liu, C.; Wang, J.; Peng, J.; Peng, R.; Soberon, M.; Bravo, A.; et al. FOXA transcriptional factor modulates insect susceptibility to Bacillus thuringiensis Cry1Ac toxin by regulating the expression of toxin-receptor ABCC2 and ABCC3 genes. Insect Biochem. Mol. Biol. 2017, 88, 1-11. [CrossRef]

129. Coates, B.S.; Siegfried, B.D. Linkage of an ABCC transporter to a single QTL that controls Ostrinia nubilalis larval resistance to the Bacillus thuringiensis Cry1Fa toxin. Insect Biochem. Mol. Biol. 2015, 63, 86-96. [CrossRef]

130. Pauchet, Y.; Bretschneider, A.; Augustin, S.; Heckel, D.G. A P-glycoprotein is linked to resistance to the Bacillus thuringiensis Cry3Aa toxin in a Leaf BEETLE. Toxins Basel 2016, 8, 362. [CrossRef]

131. Flagel, L.E.; Swarup, S.; Chen, M.; Bauer, C.; Wanjugi, H.; Carroll, M.; Hill, P.; Tuscan, M.; Bansal, R.; Flannagan, R.; et al. Genetic markers for western corn rootworm resistance to Bt toxin. G3 Bethesda 2015, 5, 399-405. [CrossRef]

132. Bretschneider, A.; Heckel, D.G.; Pauchet, Y. Three toxins, two receptors, one mechanism: Mode of action of Cry1A toxins from Bacillus thuringiensis in Heliothis virescens. Insect Biochem. Mol. Biol. 2016, 76, 109-117. [CrossRef] [PubMed]

133. Stevens, T.; Song, S.; Bruning, J.B.; Choo, A.; Baxter, S.W. Expressing a moth abcc2 gene in transgenic Drosophila causes susceptibility to Bt Cry1Ac without requiring a cadherin-like protein receptor. Insect Biochem. Mol. Biol. 2017, 80, 61-70. [CrossRef] [PubMed]

134. Atsumi, S.; Miyamoto, K.; Yamamoto, K.; Narukawa, J.; Kawai, S.; Sezutsu, H.; Kobayashi, I.; Uchino, K.; Tamura, T.; Mita, K.; et al. Single amino acid mutation in an ATP-binding cassette transporter gene causes resistance to Bt toxin Cry1Ab in the silkworm, Bombyx mori. Proc. Natl. Acad. Sci. USA 2012, 109, E1591-E1598. [CrossRef] [PubMed]

135. Endo, H.; Tanaka, S.; Adegawa, S.; Ichino, F.; Tabunoki, H.; Kikuta, S.; Sato, R. Extracellular loop structures in silkworm ABCC transporters determine their specificities for Bacillus thuringiensis cry toxins. J. Biol. Chem. 2018, 293, 8569-8577. [CrossRef] [PubMed] 
136. Guo, Z.J.; Kang, S.; Zhu, X.; Xia, J.X.; Wu, Q.J.; Wang, S.L.; Xie, W.; Zhang, Y.J. Down-regulation of a novel $\mathrm{ABC}$ transporter gene (Pxwhite) is associated with Cry1Ac resistance in the diamondback moth, Plutella xylostella (L.). Insect Biochem. Mol. Biol. 2015, 59, 30-40. [CrossRef] [PubMed]

137. Locher, K.P. Mechanistic diversity in ATP-binding cassette (ABC) transporters. Nat. Struct. Mol. Biol. 2016, 23, 487-493. [CrossRef] [PubMed]

138. Zhang, J.; Khan, S.A.; Hasse, C.; Ruf, S.; Heckel, D.G.; Bock, R. Pest control. Full crop protection from an insect pest by expression of long double-stranded RNAs in plastids. Science 2015, 347, 991-994. [CrossRef]

139. Malik, H.J.; Raza, A.; Amin, I.; Scheffler, J.A.; Scheffler, B.E.; Brown, J.K.; Mansoor, S. RNAi-mediated mortality of the whitefly through transgenic expression of double-stranded RNA homologous to acetylcholinesterase and ecdysone receptor in tobacco plants. Sci. Rep. 2016, 6, 38469. [CrossRef]

(C) 2019 by the authors. Licensee MDPI, Basel, Switzerland. This article is an open access article distributed under the terms and conditions of the Creative Commons Attribution (CC BY) license (http://creativecommons.org/licenses/by/4.0/). 